\title{
Electronic (Online) Voting in Ukraine: Realities and Prospects
}

\author{
Yuliia Lomzhets ${ }^{1 *}$, Iryna Dmytruk ${ }^{1}$, and Ihor Dubinskyi ${ }^{1}$ \\ ${ }^{1}$ Admiral Makarov National University of Shipbuilding, 54025, Ukraine
}

\begin{abstract}
The article considers the process of introduction of electronic voting in the electoral systems of modern countries and the condition of implementation of electronic democracy instruments in Ukraine. The main normative legal acts that have been adopted in recent years and the international experience of using the online voting system are analyzed. Prospects for further introduction of electronic voting in Ukraine, the main problems and possible ways to solve them are highlighted.
\end{abstract}

\section{Introduction}

The formation of Ukraine as a modern democratic, social and legal state encourages it in all ways to ensure the realization of human and civil rights, defined by the Constitution of Ukraine and international law. A significant role among them is played by a group of political rights, because according to Part 3 of Art. 21 of the Universal Declaration of Man, the will of the people must be the basis of the power of government; that the will must be manifested in periodic non-falsified elections [1].

Despite the fact, that Ukraine gained independence almost thirty years ago, our state is still in the process of finding an optimal electoral system. That is eloquently evidenced by the fairly frequently changing electoral legislation. Thus, the modern bill was submitted to the parliament on October 2, 2015, but it was developed on the basis of the draft of Electoral Code of Ukraine, which found a positive opinion of the Venice Commission and was registered in March 2010. And only on November 7, 2017 Verkhovna Rada adopted the Electoral Code in the first reading. In the future, the project was called "the largest in history", because from the deputies received about 4.5 thousand of amendments and the volume of the act was very large (460 pages).

Only on December 19, 2019 Verkhovna Rada adopted the Electoral Code as a whole [2].

However, society does not stand still and with the development of scientific and technological progress it changes, and its information components are constantly evolving and inextricably linked with the daily functioning of both man and the state as a whole.

As Yu. Danko and N. Belotserkovskaya aptly point out, in the era of the information society, when the amount of information and knowledge in the life of society increases, the role of information technologies in public and political-legal relations increases accordingly. The application of new information and communication technologies is changing political life, public discourse and tools for mobilizing citizens of many countries around the world [3, p. 61].

It is worth saying, that the issue of introducing of the system of electronic elections and approaches to their organization has been studied by such foreign and native scientists as A. Barikova, N. Belotserkovskaya, A. Gotun, Yu. Danko, N. Gritsak, H. Kokhalik, A. Konstantinovskaya, A. Nasibulin, R. Nachos, V. Peter, I. Polovko, I. Sidenko, N. Titovskaya, G. Sheludko, M. Chevallier, M. McGaley, PJ Gibson, M. Remmert and others.

Unfortunately, the COVID-19 epidemic and as a consequence of the introduction of quarantine in our state have shown the need for further legislative introduction of e-democracy, in particular, in the electoral process. In turn, this necessitates a comprehensive, in-depth study of the current state of implementation of electronic voting in the electoral system of Ukraine and the prospects for its development, taking into account international experience.

\section{Main part}

Turning to the main material of the study, it is worth saying, that today in Ukraine the development of edemocracy and e-elections is still under discussion, but the issue of introducing e-voting is not new. The legal preconditions for the functioning of the electronic election system were created by the introduction of the laws of Ukraine "On Information" of October 02, 1992 № 2657-XII, "On Electronic Documents and Electronic Document Management" of May 22, 2003 № 851-IV and "On Electronic Digital Signature" of 22 May 2003 № 852-IV, that now is invalid.

On June 10, 2011, the draft law of Ukraine "On the Concept of Implementation of the Electronic Voting System in Ukraine" № 8656 was submitted to Verkhovna Rada of Ukraine.

\footnotetext{
* Corresponding author: ylomzhets@gmail.com
} 
According to Section 3 of this bill, the introduction of electronic voting technology along with the traditional procedure has the following advantages:

- significant reduction of risks of pressure on the will of citizens;

- ensuring the possibility of voting within a few days;

- avoidance of negative phenomena, in particular forgery of ballots, photographing of counted ballots, their change in order to make them fictitious etc;

- providing the possibility of conducting an electronic referendum and bilateral communication between the state, local governments and citizens;

- increasing the number of citizens and, above the all, young people participating in the voting;

- significant savings of material resources [4].

At the same time, the main emphasis in the text of the draft was made on the last point, and the introduction of the electronic voting system was proposed to be carried out in five stages.

Thus, in particular, the author of the bill singled out the following sequence of necessary actions:

1) development, processing and adoption of the state program;

2) implementation of economic calculations and estimation of one-time expenses for formation of budgets of two levels, and also attraction of other material resources;

3) ensuring the implementation of the program taking into account international experience and with maximum use of native intellectual potential;

4) bringing the current legislation of Ukraine in line with established norms and requirements, carrying out experimental testing of electronic systems on models and analogues;

5) development of a full-scale working project and its implementation [4].

The document also outlined the practice of using electronic voting in countries such as Switzerland, Estonia, Kazakhstan, the United States, India, Brazil, Australia and South Korea, and the technical requirements for the voting system. However, the bill was withdrawn, although the argumentation of the benefits of implementing such a system remains relevant today.

The next step in implementing the e-voting system in Ukraine was the adoption in November 2017 the Order of the Cabinet of Ministers of Ukraine "On approval of the Concept for the development of edemocracy in Ukraine and the action plan for its implementation" № 797-r. The concept provided the formation of the foundations for the establishment of various forms of e-democracy in two stages.

Among the main provisions that were related to the formation of the electronic voting system at the first stage (2017-2018) were the following:

- formation of regulatory support;

- ensuring the availability of e-democracy tools for all individuals;

- improvement of the tool for electronic petitions and consultations, the mechanism of openness of information on the activities of public authorities;
- formation of the regulatory framework for the introduction of electronic voting, as well as the electronic electoral process, electronic referendums and electronic plebiscites;

- development of electronic identification of individuals and legal entities in state information and telecommunication systems [5].

Later, at the second stage (2019-2020), it was assumed:

- the introduction of network services in the field of e-democracy and the creation of conditions for their proper provision;

- direct implementation of electronic voting, as well as the electronic electoral process, electronic referendums and electronic plebiscites;

- the spread of e-democracy, the formation of knowledge and skills in using its tools among the population;

- ensuring further implementation and accessibility of e-democracy tools;

- carrying out a study of the state development of edemocracy in Ukraine;

- ensuring coordination and control over the development of e-democracy in Ukraine [5].

In turn, to implement the provisions in June 2019, the government approved the "Action Plan for the implementation of the Concept of e-democracy in Ukraine for 2019-2020", which details the sequence of actions, the timing of their implementation, responsible persons and partners. At the same time, the creation of a regulatory framework to ensure the introduction of electronic voting was expected in the III quarter of 2020 [6].

In part, one of the positive results of the action plan was the introduction of the Resolution of the Cabinet of Ministers of Ukraine "Issues of the Unified State Web Portal of Electronic Services of the Unified State Portal of Administrative Services" dated December 042019 № 1137 Portal "Action" as a service through which the idea of "state in a smartphone" is realized.

This provision defines the goals, objectives, functional capabilities and subjects of the Unified State Web Portal of Electronic Services Portal "Action" contained in it and the procedure for their introduction, as well as other issues of its operation.

The provision also assumed that from January 1, 2020, the Unified State Web Portal of Electronic Services will also perform the functions of the Unified State Portal of Administrative Services. In turn, the web portal has an official address on the Internet diia.gov.ua, and you can use the Portal "Action" for free without any time limit.

Among the main tasks of the Action Portal, the position defines the following:

- provision of electronic services (including administrative) with the receiving and using, if necessary, of information from national electronic information resources, which is necessary for the provision of such services;

- creation and functioning of the electronic cabinet of the user on the web portal, and also access through the specified cabinet of users to the information from 
national electronic information resources, including information about the person;

- submission of electronic appeals through a web portal, etc;

- providing official electronic correspondence during the provision of services, consideration of appeals and administrative cases (cases considered by executive authorities, local governments, their officials, other entities that are legally authorized to perform public authority functions, to make decisions of individual action aimed at establishing, changing, terminating or exercising the rights and obligations of a person, as well as the protection of his rights), as well as when considering using the web portal other issues;

- payment of the administrative fee for the provision of administrative services, fines for administrative offenses, state fees, other payments;

- settlements of other public (in particular housing and communal) services;

- providing the subjects of the appeal with information on the progress and results of the provision of services, consideration of the appeals and the admin in real time;

- receiving by the subjects of the appeal the results of the provision of e-services, consideration of appeals and administrative cases;

- filing complaints on the results of services, consideration of appeals and administrative cases, providing official electronic correspondence during appeal procedures, providing the appellant with information on the progress and results of the complaint in real time, as well as receiving the specified results;

- formation by means of a web portal, including with use of the mobile application of the Portal "Action", digital images of documents which the person can present on the smartphone through the specified mobile application;

- monitoring and evaluation of the quality of services provided using the web portal, in the Centers for the provision of administrative services or by the subjects of consideration of appeals directly;

- protection of data (including personal) of the specified web portal from unauthorized access, destruction, modification [7].

Equally important was the normative introduction in Ukraine the functioning of the electronic identification system. Thus, the Resolution of the Cabinet of Ministers of June 19, 2019 № 546 approved the Regulations on the integrated electronic identification system, which established the procedure for determining, defining the structure, functioning of the integrated electronic identification system, its creation and use.

The system is an integral part of the information and telecommunication infrastructure, providing electronic interaction of the subjects of interaction with the users of the system, and the owner of the system is the state [8].

A key element of electronic identification was the creation of the Resolution of the Board of the National
Bank of Ukraine of March 17, 2020 № 32 BankID System of the National Bank of Ukraine (the BankID System of the NBU).

According to the provisions of the above resolution, the BankID System of the NBU is a national electronic remote identification system, performs accounting functions and provides electronic remote identification of individuals by transmitting personal data of users by the subscriber to the subscriber - service provider, and also records the number and volume of services remote identification [9].

According to the information, posted on the official website of the NBU, the BankID System currently has 33 subscribers, including:

- 14 banks (CB "Privatbank", JSC "Sberbank", JSC "Alfa Bank", JSC "FUIB", Monobank (JSC "Universal Bank"), A-Bank (JSC "Accent-Bank"), JSC "Alliance", JSC "FORWARD Bank", JSB "Pivdenny", JSC " Kredobank", JSC JSB "Radabank", JSC "MotorBank", JSC "Bank Vostok", JSC "Idea Bank");

- 19 other institutions (service portals) [10].

Thus, after the implementation of all these measures, the government expected to provide the basic elements of e-democracy in all spheres of public life. But, given the timing and huge range of necessary actions, insufficient development of information and telecommunications resources and security tools, storage of information on servers, which must have strong protection against any interference, it is impossible to fully implement the above plan.

The second important step in the process of formation of electronic voting was also the adoption of the above-mentioned Electoral Code of Ukraine dated December 19, 2019 № 396-IX.

In accordance with Article 18, the Central Election Commission may decide to introduce innovative technologies, hardware and software in the organization and conduct of elections in the form of an experiment or pilot project on:

1) voting of voters at the polling station with the help of technical means and software (machine voting);

2 ) conducting the counting of votes with the help of technical means for electronic counting of votes;

3 ) drawing up protocols on the counting of votes, results and results of voting using the informationanalytical system [11]. Analyzing this norm, we can conclude that, despite the presence in international experience of several forms of electronic voting, the legislator ignores them, including online voting, and considers only one its form.

Today, there are three main forms of electronic voting in the world:

- voting via the Internet (online) - voters use a personal computer with an Internet connection, which receives the voter's voice and transmits it to another computer, remote access computer;

- voting in the booth with the help of "electronic ballot boxes" - the interface of such a system can be a touch screen or a scanner that reads the mark, placed by the voter in the ballot. Then the voice is registered and stored in the device for e-voting. Thus, citizens 
vote in their traditional polling station only with the use of information technology;

- voting using a mobile phone, which can combine pre-specified forms [12, p. 77].

At the same time, the use of "electronic ballot boxes" remains the most widespread form of electronic voting. This type of voting is popular because "electronic ballot boxes" can operate autonomously, without being connected to power grids and communications, which is especially important in countries where polling stations are located in sparsely populated areas or in areas with limited access to telephone lines and the absence of the Internet. [13, p. 17].

The electronic voting system was first introduced in Brazil. In 1996, the system was successfully tested in municipal elections in 57 cities, by 2000 the system was applied in municipal elections throughout the country, and in 2002 this experience was applied in the world's first electronic national elections of the head of state. The elections were observed both by representatives of different countries of the world (USA, Japan, Mexico, Venezuela) and by representatives of the international organization "Transparency International", who confirmed that the voting procedure excluded the possibility of fraud and abuse during the expression of will [14, p. 52].

The first experiment with online voting was carried out in 2000 in the state of Oregon, USA. Over time, voting technologies have improved. Complexes for electronic voting have been widely used in local and federal elections in the United States. In 2002, the Federal Law "Help America Vote Act" was passed. The purpose of the Law was to reject paper ballots, lever devices (voters press the lever next to the candidate's name) and punch-card machines (holes are punched on special cards next to the names of candidates) [15, p. 59].

The experience of some Asian countries is in terms of the use of electronic means in the conduct of elections. So, in 2005 , for all political elections in Korea, an electronic voting system was introduced, the tests of which began in 2004. Korea became the first Asian country to vote in all political elections electronically. In trial mode, the new voting system began operating in 2004. In turn, already in 2005, the entire state document circulation was digitized, and in 2006 a database of basic civil documents was created to improve the efficiency of the government, which made it possible to reduce costs. In 2007, the government established a national information network to monitor the import / export of goods by rail and road through customs. [4]

Asian countries, including Japan, Taiwan and Hong Kong, have also launched pilot projects for e-voting systems. In June 2002, residents of the city of Niimi, about $500 \mathrm{~km}$ from Tokyo, became the first in Japan to use the electronic electoral system. According to the Associated Press, more than 15,000 people made their choice by placing their fingers on the touch screens of voting machines with using the biometric parameters of voters [4].
The most preferable and close to Ukraine example in the field of legislative implementation of electronic voting is Estonia. Since the introduction of Internet voting in 2005 in local elections, this voting method has been used here 7 times: in October 2005, 2009 and 2013 in local elections, in 2007 and 2011, in parliamentary elections in 2009 and 2014, in elections in European Parliament. The number of voters who voted online also grew over the years from $2 \%$ in 2005 to $31 \%$ in 2014 , despite massive hacker attacks, which, during the 2007 elections, did not undermine the confidence of the country's citizens in e-voting [3, p. $66]$.

India's experience is also interesting and quite unusual for the modern understanding of electronic voting. For example, the Indian Voting Machine, or EVM (Electronic Voting Machine), was developed in 1989-90. The device consists of two modules - a control unit and a console for voting. The console has a list of candidates, next to each of which is a vote registration button. After pressing it, the input device is locked until the next voter, and the fixed voice is entered into the memory cell of the corresponding candidate. The control unit is entrusted with the functions of the general support of the process of issuing the total number of citizens who voted and the final announcement of the election results. For security reasons, electronic machines are not connected to any networks and central databases, and voting results are recorded by members of the regional election commission. Thanks to such technical solutions, the electronics of the voting machine do not require any operating system, all command codes are sewn directly into the chips, and the system is therefore considered extremely resistant to unauthorized interference, in particular hacker attacks [4].

But such an electoral system is categorically not accepted by the opposition, as EVM is manufactured by state-owned enterprises and those controlled by the "ruling party". It has been shown that, contrary to the assurances of the manufacturers and the election commission about the "resistance of the machine to hacking", the motherboard is easily and without loss of functionality removed from the EVM case, chip code is read, and chips can be changed to reprogrammed. As a result, such a modified machine does everything as it should, but eventually removes a certain share of votes from all memory cells and adds them to the votes that are "needed", guaranteeing victory to the right candidate and maintaining the total number of voters who voted [4].

The experience of Switzerland is interesting, where in 2003 an experimental electronic voting through the "E-voting" system took place for the first time. According to the plans of the Swiss government, the absolute majority of citizens, even those who were outside their country, could already vote in the next parliamentary elections in 2015 on the Internet. Switzerland is constantly expanding the use of evoting. Today in Geneva, about $30 \%$ of local voters carry out online voting. In order to improve the security of the electoral process, an electronic voting 
procedure with authorization under an individual code was introduced [16, p. 171].

Also, no less important is the experience of the Swiss city of Zug, in which in 2018 an experiment with the use of technology in the field of cryptographic protection - Blockchain, which allows creating open and protected data registries in the electoral process [17], was successfully completed.

Another successful experiment in 2018 was the online elections in West Virginia, USA, which were supported by the private project Voatz. This project is a platform for blockchain-based Internet voting, which can then be used at the state level. The project is currently being tested. Also a popular project in the United States in this area is the Follow My Vote project. The developers seek to create a platform for voting, which will achieve transparency in the election, without compromising the confidentiality of voters, as well as to provide mathematical algorithms to obtain an accurate election result [18, p. 83].

It should be noted that the Central Election Commission of Ukraine also tested the NEM blockchain protocol for storing polling station protocol data in 2014 during the presidential elections in Ukraine [18, p. 83].

In turn, the government of Kazakhstan was also interested in the formation of an electronic voting system and in September 2000 electronic elections were held. By Presidential Decree, a State Government Working Group was established to develop changes and additions to the country's legislation. In 2004, electronic equipment was purchased and operators were trained. In April 2004, amendments to the Law on Elections were adopted, which provide for an electronic voting procedure. Appropriate additions have also been made to administrative and criminal legislation [4].

Taking into account the fact that Ukraine has long taken the course of European integration, an analysis of the normative acts of the Council of Europe is important for the legislative support of the functioning of the electronic voting system in Ukraine.

According to the Council of Europe Recommendations on Legal, Operational and Technical Standards for Electronic Voting No. 11 dated September, 30, 2004, a number of principles must be observed for the use of electronic voting systems. The elections must be accurate, with the guarantee of transmission of the electronic vote to the central network without any changes. It is necessary to adhere to the democratic principles of traditional elections - direct, free, general, with the provision of procedures for secrecy and transparency. When conducting electronic voting, it is important to adhere to the privacy policy and ensure that it is impossible to identify the voter with his vote. The last important principle is the possibility of verification and audit of votes, when each voter will be able to check the correctness of accounting for his vote [9].

To the requirements described above, J. Gibson, M. McGaley and M. Chevallier added a number of criteria for the proper functioning of the electronic election system. In particular, an electoral vote cannot be detected and changed during its transfer to the election commission. Only registered voters have the right to vote, and only once, a second vote will be considered election fraud. The voting site must be protected from hacker attacks and protect the personal data of voters. The state must ensure the impossibility of pressure on citizens through convictions; introduce a ban on the purchase / sale of votes with criminal responsibility $[18$, p. $5 ; 19$, p. 4].

The Cabinet of Ministers of the Council of Europe has outlined general standards for regulating the evoting procedure, which reflect the basic principles of democratic elections and strengthen confidence in the e-voting procedure. They are the guiding lines for the widespread implementation of the electronic voting system in the member states of the European space.

The standards can be divided into three types: legal, defining international and national regulations governing the election procedure; operating standards that govern the organization of elections and the voting procedure itself; technical standards to ensure the compatibility of software and electronic devices. The selected requirements must be applied at all stages of the elections: announcement of elections, registration of voters, registration of candidates, campaigning, voting procedure, calculation of results and their protection [20, p. 13].

These provisions were updated in 2017 with the adoption of CM / Rec (2017) 5, which clarified the definition of electronic voting to include electronic ballot counting. However, other electronic voting tools that are used during the electoral process, in particular electronic registers, methods of processing information about voters, counting votes, transfer of results, were not included with the provisions of the above recommendations [23].

However, the regulation of the electoral process, first of all, has a national prerogative, and therefore its international legal principles are contained in the national constitution and / or national electoral legislation, and in some countries local elections are governed by local legislation. However, in general, all normative legal acts (supranational, national and local) contain general principles that are enshrined in international documents.

With this in mind, the Council of Europe's electoral administration and civil society in its publication "Digital Technologies in Elections. Question, conclusions and prospects" summarized the characteristics of the national legislation of European countries on the issue of electronic voting. Thus, the authors found that the introduction of technologies in the electoral process was carried out in two waves. Legislators first regulated the use of simple technologies (paper and mechanical), particularly in the 1960s and 1970s in Germany, the Netherlands and France. Later, the legal framework was "updated", taking into account technological progress, and mainly concerned the use of devices for electronic voting or 
electronic counting in the 1990s. In turn, the countries that introduced Internet voting in their electoral process developed special regulatory acts, although they were formed by analogy with the existing "paper" systems, namely, voting by mail (Switzerland or Estonia at the beginning of 2000) [24, p.12].

However, the authorized bodies of Austria recognized that the legal regulation of Internet voting does not comply with the constitution for its insufficient detail and as such that cannot allow members of election commissions to fulfill their duties without technical assistance [24, p.13].

The jurisprudence of the highest national courts has also played an important role in clarifying the practical significance of electoral principles in the context of their application in the e-voting procedure. The decisions of the constitutional courts of Germany (2009) and Austria (2011) attracted particular attention. The jurisprudence has demonstrated the importance of interpreting the principles in terms of their transformation into detailed requirements for technologies and helped to form a general agreement on the need for detailed regulation of digital technologies. It showed that the same principles can be interpreted in very different ways, which ultimately leads to different results depending on the factual, historical, cultural characteristics. The preparation of such an interpretation must be put on the legislator/regulator, and not on technical workers or technology suppliers [24, p.13].

Thus, the Netherlands returned to paper voting in 2008 , the main reasons were the danger of secrecy of the voice and a large dependence on sellers and certified agencies. As already noted, Germany in 2009, declared the e-voting procedure unconstitutional due to a lack of publicity. Unlike Norway, which in 2014, temporarily suspended the process of introducing evoting in the context of the security problem $[16, p$. 171].

Also, despite the existing regulations and the positive experience of countries, a common problem for all is the threat to the security of election results, in particular, possible hacker attacks on election servers. Ukraine has already had precedents with insufficient IT-protection of state structures from such threats. A striking example is the actual paralysis of the activities of public authorities due to infection with the "Petya" virus in June 2017 and the information about the leakage of personal data of citizens from the digital state service of the "Action" application in April 2020. And although about the latter, the Cyber Police Department of the National Police of Ukraine did not reveal the facts of cyber attacks, but in fact there was a seizure of personal data of citizens, although outdated. In addition, the practice of much more technically developed states also testifies to the danger of such situations.

Such an example is the scandal surrounding the possible interference of Russian hackers in the 2016 US presidential elections, when, before the start of the procedure, as a result of a cyber attack on the servers of the US Democratic National Committee (DNC), came almost 20,000 emails written or received by committee officials. The hackers also attacked the Democratic Congress Committee (DCCC). American Internet security experts blamed the attacks on Russian hacker groups called Cozy Bear and Fancy Bear. [21]

According to Microsoft vice president of user security Tom Burt, in 2019 the latter named group of hackers tried to gain access to the personal data of political advisers working for both the Democratic and Republican parties, as well as representatives of the expert community - in general, they felt attacks on themselves. more than 200 organizations [21].

Also, the problem of such a system using the global Internet for Ukraine is the insufficient level of access of the electorate to the network. This manifests itself in two aspects:

- first, high-quality Internet in remote settlements in our state, unfortunately, is absent today;

- secondly, the complexity of the e-voting system for some categories of Ukrainian, in particular the venerable age, due to the lack of knowledge and skills necessary for electronic expression of will, which creates a threat of dividing society into those who have a sufficient amount of information and those who do not owns and therefore is limited in its rights.

A. Weyer aptly notes that a weak point in the electoral system and elections through the Internet in Ukraine can be considered the difficulty of identifying a particular voter, which may result in two options:

1. In the first situation, a citizen-voter at an convenient time, before election day, receives an individual electronic key or password that will allow him to register on the server to vote. If such a key is issued, like a passport, for a long period of time and, accordingly, will be stored for a long time with one owner, the reliability of passwords is reduced. They can be stolen from the voter himself or from a database for storage. Thus, the amount of time taken to store the password is inversely proportional to its reliability;

2. In the second scenario, the password is given to the voter immediately before the election and is valid once. With such a system, the reliability of the password does not cause complaints, but the fact that the voter before each local or national election has to go to the polling station, where individuals will give him a password, at least halves the usefulness and convenience of electronic voting as such [26, p. 266].

Thus, we can identify the following main problems of the introduction of electronic voting in Ukraine:

- imperfection of the legal regulation of the electronic voting procedure, calls into question the observance of the general principles of the electoral process (anonymity of voting, publicity, etc.);

- threat to the security of the election results, due to insufficient technical support of the procedure;

- insufficient level of informatization of the Ukrainian electorate.

Nevertheless, despite a number of these shortcomings, the electronic online voting system in the electoral process also has a number of advantages, including more accurate results and faster counting of votes; preventing abuses in the counting of results at 
polling stations by reducing human interference; the ability to vote from abroad; the possibility of voting for sick voters and people with disabilities; reducing the number of spoiled ballots, as electronic electoral systems can warn voters about invalid votes; saving money by saving time of employees, reducing the cost of producing and distributing ballots, in order to avoid costs of transporting ballots; reduction of incidents of sale of votes, excluding voting by one voter in several constituencies [3, p. 69].

\section{Conclusion}

It can be concluded, that modern technologies and their introduction into the political system of many countries of the world, including Ukraine, change the vector of development of society as a whole, and become an effective tool for attracting citizens to decision-making through the introduction of e-democracy mechanisms. The use of such technologies in the electoral process is acquiring a wide range of development, especially through electronic voting, which, even with certain disadvantages and economic difficulties, is becoming more widespread in world democracies.

It is also positive for Ukraine that e-voting is a significant saving of financial resources aimed at:

- ensuring the electoral process;

- reducing the risk of infection, since the contact of citizens is minimal;

- the care for the environment is manifested due to the decrease in the use of paper information carriers.

Today Ukraine has adopted basic regulatory legal acts and partially implemented the first technical capabilities that can be used to further ensure the application of electronic online voting and edemocracy, but the ultimate prospect of introducing an electronic voting system in Ukraine is questionable in the coming years. Since the main problem is not only the lack of a full-fledged legal framework, but also the vulnerability of native electronic systems from negative information influences, viruses, hacker attacks and the possibility of manipulation and outside interference in the results of the expression of the will of citizens.

That is why, before seriously approaching the implementation of electronic voting, it is necessary to clearly clarify the issue of fundamental legal regulation of the introduction of an electoral mechanism for electronic online voting in Ukraine and means of protection, storage of information on servers that would have powerful protection against any hacker interference and implement incentive measures informatization of all categories of society.

\section{References}

1. Universal Declaration of Human Rights of December 10, 1948. URL:

https://zakon.rada.gov.ua (access date 28.01.2021)
2. Electoral Code of Ukraine. Wikipedia: website. URL: https://en.wikipedia.org (access date 28.01.2021)

3. Yu. Danko and N. Belotserkovskaya Modern Society, Electronic Voting: Possibilities of Ukrainian Reception, № 1 (17), pp. 61, 66, 69 (2019)

4. Draft Law of Ukraine "On the Concept of Implementation of the Electronic Voting System in Ukraine” dated 10.06.2011 № 8656. Ips. ligazakon: website. URL: https://ips.ligazakon.net (access date 28.01.2021)

5. On approval of the Concept for the development of e-democracy in Ukraine and the action plan for its implementation: Order of the Cabinet of Ministers of 08.11.2017 № 797-r. URL:

https://zakon.rada.gov.ua (access date 28.01.2021)

6. On approval of the action plan for the implementation of the Concept for the development of e-democracy in Ukraine for 20192020: Order of the Cabinet of Ministers of June 12, 2019 № 405-r. URL: https://zakon.rada.gov.ua (access date 28.01.2021)

7. Question of the Unified State Web Portal of Electronic Services of the Unified State Portal of Administrative Services: Resolution of the Cabinet of Ministers of Ukraine of December 4, 2019 № 1137. URL: https://zakon.rada.gov.ua (access date January 28, 2021)

8. On approval of the Regulations on the integrated electronic identification system: Resolution of the Cabinet of Ministers of June 19, 2019 № 546. URL: https://zakon.rada.gov.ua (access date 28.01.2021)

9. On approval of the Regulations on the BankID System of the National Bank of Ukraine: Resolution of the Board of the NBU of March 17, 2020 № 32. URL: https://bank.gov.ua (access date 28.01.2021)

10. Created prerequisites for the implementation of a commercial model of using the BankID System of the NBU. National Bank of Ukraine: website. URL: https://bank.gov.ua (access date 28.01.2021)

11. Electoral Code of Ukraine: Law of Ukraine of 19.12.2019 № 396-IX. URL: https://zakon.rada.gov.ua (access date 28.01.2021)

12. G. Sheludko Recent Studies of Social Sciences. Section: Politics, Electronic voting as a kind of selective information and communication technologies: foreign and domestic experience, $\mathrm{p}$. 77 (2015)

13. A. Barikova Electronic state: a new management efficiency, P. 17 (2016)

14. A. Gotun Journal of Taras Shevchenko National University. Series: Philosophy. Political Science, The use of new information technologies in the electoral process: world experience and practice in Ukraine, № 89-90, P. 52 (2008) 
15. P. Nachos Comparative and Analytical Law, Electronic Voting in Ukraine: Prospects for Implementation and World Experience, № 1, P. 59 (2018) URL: http://pap-journal.in.ua (access date 28.01.2021)

16. H. Kokhalik Efficiency of public administration, World experience of introduction of electronic democracy: problems and achievements, № 42, p. 171 (2015)

17. Switzerland's first municipal blockchain vote hailed a success. SWI swissinfo.ch : website. URL: https://www.swissinfo.ch/eng/cryptovalley-_switzerland-s-first-municipal-blockchainvotehailed-a-success/44230928 (date of access 02.21.2021)

18. A. Chernyshev Actual problems of public administration, Internet voting as a tool of public administration in Ukraine, No. 3 (79), pp. 79-84 (2019)

19. Counsil of Europe. Recommendation on legal, operational and technical standards for e -voting explanatory memorandum. Rec. (2004) 11. URL: https: // www. coe. int / t / dgap / goodgovernance / Activities / Key - Texts / Recommendations / LinkEvotingRec _ en. asp (access date 28.01.2021)
20. Chevallier M. Internet voting: Status, perspectives and Issues. In TU-e-Government Workshop, P. 5 (2003)

21. McGaley M. \& GibsonP.J. E-voting: a safety critical system, P. 4 (2003)

22. Remmert M. Towards European Standards on Electronic Voting. In Electronic Voting in Europe. P. 13 (2004)

23. Recommendation $\mathrm{CM} / \mathrm{Rec}$ (2017) 5 of the Committee of Ministers to member States on standards for e-voting. URL: https://rm.coe.int/0900001680726f6f (date of access 02/21/2021)

24. A. D. Maurer Digital technologies in elections. Question, conclusions and perspectives, pp. 10-12 (2020)

25. Microsoft: Russian hackers are again interfering in the US elections. Deutsche Welle : website. URL: https://www.dw.com/uk/microsoft-rosiiskikhakery-znovu-vtruchaiutsia-u-vybory-v-ssha/a54890149 (date of access 02/21/2021)

26. A. Weyer Current policy issues, Advantages and disadvantages of voting on the Internet, Vol. 60, P. 266 (2017) 